\title{
Krueppel-Like Factor 4
}

National Cancer Institute

\section{Source}

National Cancer Institute. Krueppel-Like Factor 4. NCI Thesaurus. Code C73453.

Krueppel-like factor 4 (470 aa, $\sim 50 \mathrm{kDa}$ ) is encoded by the human KLF4 gene. This protein regulates transcription. 